\title{
Assessment of Cardiovascular Parameters during Dental Procedures under the Effect of Benzodiazepines: A Double Blind Study
}

\author{
Fatima Neves FARACO ${ }^{1}$ \\ Paschoal Laércio ARMONIA ${ }^{1,2}$ \\ José Leonardo SIMONE ${ }^{1}$ \\ Nicolau TORTAMANO ${ }^{1,2}$ \\ ${ }^{1}$ Department of Stomatology, Faculty of Dentistry, University of São Paulo, São Paulo, SP, Brazil \\ ${ }^{2}$ Department of Stomatology, Faculty of Dentistry, UNIP, São Paulo, SP, Brazil
}

\begin{abstract}
The purpose of this study was to evaluate cardiovascular parameters during dental procedures: systolic, diastolic, and mean blood pressures, and heart rate. Nineteen healthy normotensive patients (18-56 years of age) received restorative treatment on three maxillary molars. The patients were continuously monitored by a non-invasive automatic monitor for blood pressure and heart rate during the pre-, trans-, and post-operative periods at the following stages: $15 \mathrm{~min}$ prior to anesthesia; during topical anesthesia; during infiltrative anesthesia; for 5 minutes immediately after; during cavity preparation; during restorative procedure; for $10 \mathrm{~min}$ after completion. Patients were divided into three groups: A (without pre-medication), B (preceded by $10 \mathrm{mg}$ diazepam), and C (preceded by placebo). All patients received infiltrative anesthesia containing $1.8 \mathrm{~mL}$ of $2 \%$ lidocaine $(36 \mathrm{mg})$ with epinephrine $1: 100,000(18 \mu \mathrm{g})$. There were no changes in the parameters during the clinical procedures. When groups were compared, there were significant differences in diastolic arterial pressures during anesthesia.
\end{abstract}

Key Words: cardiovascular alterations, lidocaine, benzodiazepines, epinephrine.

\section{INTRODUCTION}

Anxiety and stress are experienced by many patients during dental treatment. Because this is a major health problem, much study has been done to measure the body's physiologic response to routine dental procedures. Although pain during dental procedures can be readily controlled with local anesthesia, psychological stress of the clinical environment, the discomfort associated with oral injections, and the annoyance of oral manipulations, together with fear, may produce varying degrees of non-detectable clinical cardio-circulatory changes (1-3). Anxiety experienced during a dental visit may cause parasympathetic dominance, with bradycardia and/or syncope $(4,5)$, or even cardiac arrhythmias (6). Healthy patients are usually able to tolerate these physiologic responses which are due to stress; however, patients with hypertension, heart dis- ease, cerebrovascular disease, or increased age may have a diminished tolerance to stress (7).

Benzodiazepines have long been considered the base of ansiolytic pharmacotherapies. They are among the most widely used drugs in medical science due to the fact that they are more selective, with a broad margin of safety, when compared to other hypnotic sedatives (8).

The importance of knowledge of the factors that interfere in the cardiovascular system during pre-, trans-, and postoperative periods in dental procedures, as well as the role of local anesthetics, whether preceded or not by ansiolytics, is undoubtedly fundamental, because these are the most used medications in dentistry.

\section{MATERIAL AND METHODS}

Using clinical and radiographic examinations, 
19 healthy normotensive voluntary patients (12 men and 8 women; $18-56$ years of age) were selected. They were taking no medications and required at least three restorative procedures in maxillary molar teeth. These teeth were in similar clinical and radiographic conditions, with cariogenic processes of occlusal extension (mesio-occlusal, mesio-occlusal-distal, or distal-occlusal), without irreversible inflammatory pulp, and silver amalgam restoration was indicated.

A non-invasive blood pressure automatic monitor (Scholar $^{\mathrm{TM}}$ II Model; Criticare Systems, Inc., Waukesha, WI, USA) with coupled recorder (CSI507R) was used for continuous blood pressure reading (systolic, diastolic and mean) by the oscillometric method, and heart rate, programmed for recordings each minute, was recorded by the photopletismographic method.

All 19 patients were submitted to three restorative procedures in the maxillary molars, bilaterally, and at the initial appointment no medication was administered. In the next two sessions that were 1 week apart, each patient took 1 placebo capsule (lactose) or 1 diazepam capsule $(10 \mathrm{mg})$, one hour before the appointment for anxiety control. In this double-blind study, placebo and diazepam capsules (Laboratório Fórmula e Ação; São Paulo, SP, Brazil), which were the same color, shape and texture, were code-numbered, and the code was revealed only at the end of the experiment. All patients received infiltrative anesthesia containing 1.8 $\mathrm{mL}$ of $2 \%$ lidocaine (36 mg) with epinephrine 1:100,000 $(18 \mu \mathrm{g})(2 \%$ xylocaine, Astra, São Paulo, SP, Brazil) administered at approximately $1.0 \mathrm{~mL} / \mathrm{min}$. Successive blood aspiration tests were performed using an aspiration syringe (Health Co., Minnesota, USA) to confirm that the anesthetic was not being injected into the blood stream. Topical anesthesia ( $20 \%$ benzocaine ointment, Topex, DFL, Rio de Janeiro, RJ, Brazil) was provided to all patients.

The patients were divided into three groups: group A received lidocaine with epinephrine and no pre-medication; group B received lidocaine with epinephrine preceded by diazepam; group $\mathrm{C}$ received lidocaine plus epinephrine, preceded by placebo. Thus, 57 clinical procedures were carried out in 19 patients: 19 had no pre-medication, 19 were preceded by diazepam, and 19 were preceded of placebo.

During the procedures, each patient remained sitting at the dental chair with his mouth open, so that the upper arch was 45 degrees relative to the ground.
The chair height was adjusted so that the patient's mouth would be the same level as the dentist's elbow, therefore allowing the required exactness for the infiltrative anesthesia. The patient's left arm was positioned parallel along his body, and the blood pressure device was placed at the heart level. The pletismograph finger cuff was firmly adapted to the right hand forefinger.

After patient preparation, the equipment was calibrated automatically by recording for $15 \mathrm{~min}$, which was enough to stabilize the parameters and to determine a base scale (basal period) for systolic, diastolic, and mean blood pressures, in $\mathrm{mmHg}$, as well as the heart rate, in beats/min. Clinical sessions were performed with a continuous monitoring of blood pressure and heart rate, from preparation of the patient until 10 min after the restorative procedure ended. See Table 1 for explanation of experimental stages F1-F7.

A separate statistical analysis of each group

Table 1. Experimental stages (F1-F7).

F1 for 15 min after patient's preparation prior to anesthesia
F2 for 2 min during topical anesthesia
F3 for 2 min during infiltrative anesthesia
F4 for 5 min after injection
F5 during cavity preparation
F6 during restorative procedure
F7 for 10 min after completion

during pre-, trans-, and postoperative periods was done with ANOVA. When mean differences were significant, the Tukey test was applied. A comparative analysis of the 7 stages for the 3 groups was carried out using the Student's t-test.

\section{RESULTS AND DISCUSSION}

Variations of cardiocirculatory parameters during dental treatment have long been a major concern for dentists and researchers. Several authors have reported significant changes that might affect physiologic stability in normoreactive patients $(9,10)$, and particularly in those with circulatory diseases $(4,5,11-13)$, as well as elderly patients (1). Both laboratory research $(12,14,15)$ and clinical research $(3,16)$ have evaluated changes occurring during dental procedures, in pre-, trans-, and postoperative periods $(4,5,9,10,13,17)$.

Tranquilizing drugs can be used to control auto- 
nomic nervous system responses, and to help minimize cardiocirculatory alterations $(1,6)$. The effectiveness of this group of drugs has been tested for catecholamines and other vasoconstrictors in local anesthetics $(8,13,18)$.

In the present study, possible systolic blood pressure alterations were seen in percentage variations, considering stage F1 with variation percentage zero (Figure 1). This figure shows that the greatest variation in systolic blood pressure was $-1.72 \%$, during stage F4 ( 5 min after anesthesia) for group A. In groups B and C, the greatest alteration also occurred in stage $\mathrm{F} 4(-1.58 \%$ and $-1.45 \%$, respectively).

This small percentage variation does not have a significant clinical meaning. The ANOVA F test, applied to values obtained for the 3 groups, showed that there was no statistically significant difference between means in the stages, at a significance level of 0.01 , which corroborates our position, when performing a clinical analysis, as well as the findings of other authors $(4,5,7,9,10,15,19)$.

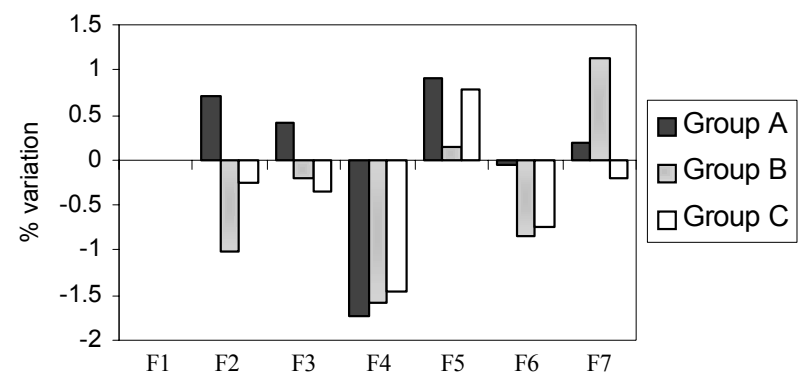

Figure 1. Systolic blood pressure percentage variation during stages F1-F7 in groups A (no pre-medication), B (diazepam), and $\mathrm{C}$ (placebo).

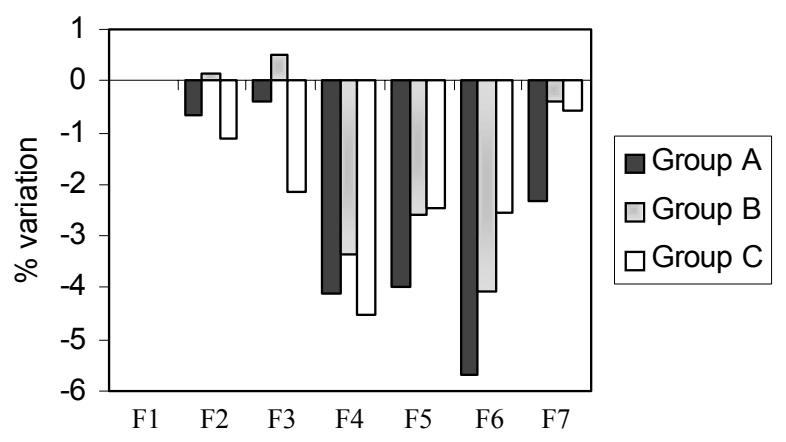

Figure 2. Diastolic blood pressure percentage variation during stages F1-F7 in groups A (no pre-medication), B (diazepam), and $\mathrm{C}$ (placebo).
The greatest changes in diastolic blood pressure occurred during stage F6 (Figure 2): group A (-5.67\%) and group B (-4.09\%). Group C showed the greatest alteration during stage F4 (-4.52\%). Analysis showed that there was no statistical difference, at a significance level of 0.01 .

The mean blood pressure (Figure 3) of groups A and $\mathrm{B}$ had the greatest alterations during stage $\mathrm{F} 6$ (group A: $-3.37 \%$; group B: $-3.24 \%$ ). In group C, the greatest alteration was in stage F4 (-3.26\%). These differences were not statistically significant.

The percent variations of heart rate for the 3 groups is shown in Figure 4. There were no significant statistical alterations. We can also observe in this figure that the greatest heart rate alterations occurred during cavity preparation (F5) in the three groups: group A $(+7.20 \%)$; group B (+9.27\%); group C $(+7.30 \%)$.

Analysis of the changes in the parameters evaluated in stages F1 to F7 for the 3 groups is in agreement with the findings of other authors $(2-5,7,9,10,19)$.

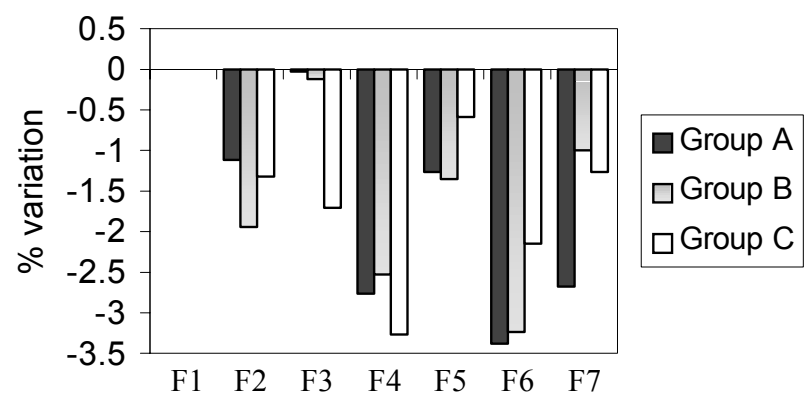

Figure 3. Mean blood pressure percentage variation during stages F1-F7 in groups A (no pre-medication), B (diazepam), and $\mathrm{C}$ (placebo).

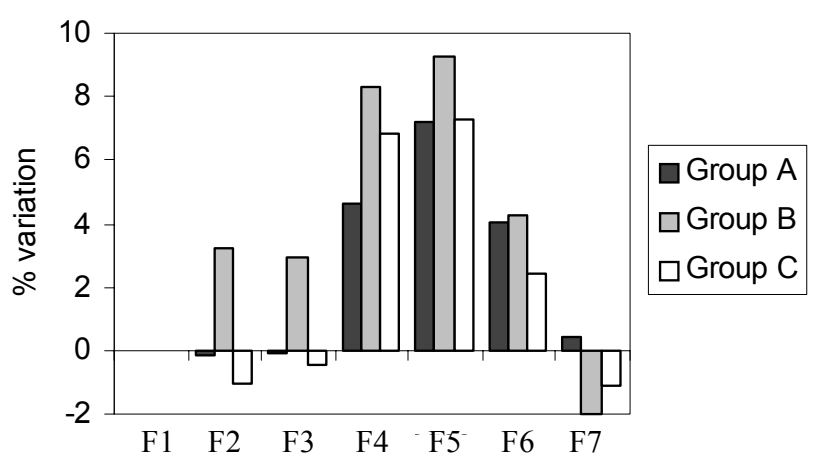

Figure 4. Heart rate percentage variation during stages F1-F7 in groups A (no pre-medication), B (diazepam), and C (placebo). 
When comparing separately the 7 stages of the 3 groups, we note that initially the parameters evaluated in stage F1 showed a similar behavior, which emphasizes the uniformity of the sample. Student's t-test, applied to values obtained in F1 (basal period) showed that there were no statistically significant differences between the means of the parameters evaluated, which

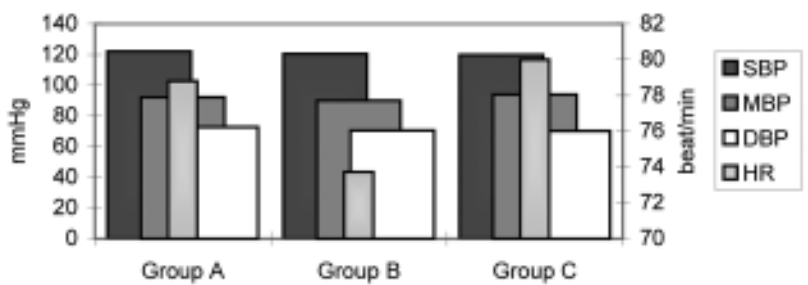

Figure 5. Average absolute values of parameters evaluated (systolic, diastolic, mean arterial blood pressures, and heart rate) in stage F1 (basal period), in groups A, B, and C.

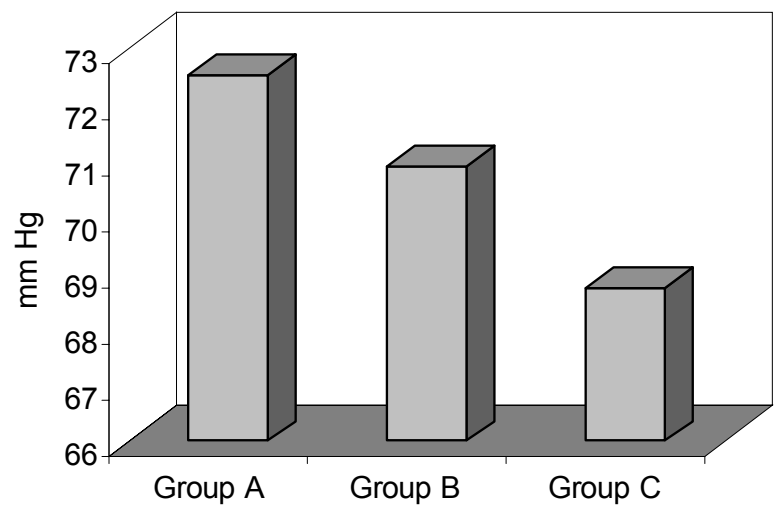

Figure 6. Diastolic blood pressure changes in stage F3, in groups $\mathrm{A}, \mathrm{B}$, and $\mathrm{C}$.

Table 2. Student's t-test summary for diastolic blood pressure in Stage F3 (infiltrative anesthesia).

\begin{tabular}{lcccccc}
\hline & Group A & Group B & Group A & Group C & Group B & Group C \\
\hline Mean & 72.5352 & 70.9136 & 72.5352 & 68.7263 & 70.9136 & 68.7263 \\
Variance & 48.7170 & 51.5387 & 48.7170 & 65.4443 & 51.5387 & 65.4443 \\
Observ. & 19 & 19 & 19 & 19 & 19 & 19 \\
Stat t & 1.25223 & & 2.92596 & $* *$ & 2.39380 & $*$ \\
Crítical t & 2.87844 & & 2.87844 & & 2.87844 & \\
two-tailed & & & & & & \\
\hline
\end{tabular}

*Significant at 0.05 level. **Significant at 0.01 level. corroborates our clinical analysis (Figure 5).

As to stage F3 (for 2 min during anesthesia), we observed that the parameters evaluated were similar, i.e., both the tranquilizer and the placebo did not interfere in cardiovascular responses. On the other hand, statistical analysis showed significant differences for diastolic blood pressure between groups $\mathrm{A}, \mathrm{B}$, and $\mathrm{C}$, as seen in Figure 6 and Table 2.

The difference between diastolic blood pressure values in groups $\mathrm{A} \times \mathrm{C}$ and $\mathrm{B} \times \mathrm{C}$ seems to be clinically relevant, and in the statistical analysis that difference was significant. There was a $3.80 \mathrm{mmHg}$ alteration between $\mathrm{A}$ and $\mathrm{C}$ (group $\mathrm{A}=72.53 \mathrm{mmHg}$ and group $\mathrm{C}$ $=68.73 \mathrm{mmHg}$ ), and $2.18 \mathrm{mmHg}$ between $\mathrm{B}$ and $\mathrm{C}$ (group $\mathrm{B}=70.91$, and $\mathrm{C}=68.73 \mathrm{mmHg}$ ). On the other hand, group B (diazepam) in stage F3, as to diastolic pressure, also presented a mean value lower than group A (no pre-medication), although this mean difference did not show a statistically significant result (Table 2).

We also observed that the parameters evaluated (systolic, diastolic and mean blood pressures, and heart rate) in stage F4 (for 5 min after anesthesia), F5 (cavity preparation), F6 (restorative procedure), and F7 (for 10 min after completion) were similar in groups $\mathrm{A}, \mathrm{B}$, and C, i.e., diazepam (group B) and placebo (group C) did not interfere in the cardiovascular responses of patients. Student's t-test, applied to values obtained in these stages for groups A, B, and C, showed that there were no statistically significant differences among the means of the parameters evaluated, which confirms our observations at the time of clinical analysis.

Finally, we should emphasize that some cardiovascular changes were observed during the clinical procedures in normotensive patients who presented normal mechanisms of physiological adjustment, and differences in diastolic blood pressure variations, at some points, were seen (biologically and statistically) among the groups. These findings suggest that in hypertensive patients, or patients presenting cardio-circulatory disease, cardiovascular alterations may be of a greater magnitude, which certainly means greater risk during clinical procedures, in agreement with the opinion of other authors (1- 


\section{$3,5-7,12-15,17)$.}

We conclude that for normotensive patients clinically and statistically significant alterations did not occur in cardiovascular parameters. Diastolic blood pressure seemed to be better controlled in group $\mathrm{C}$ (placebo). Diazepam and placebo did not show any clinical importance. Heart rate was the cardiovascular parameter which presented the greatest alterations in the groups evaluated; however, it apparently does not have a clinical significance.

\section{RESUMO}

A finalidade desse estudo foi avaliar os parâmetros cardiocirculatórios, pressão arterial sistólica, diastólica e média e freqüência cardíaca, durante procedimentos clínicos odontológicos. Dezenove pacientes, com idade entre 18 e 56 anos, normotensos, receberam tratamento restaurador em 3 dentes molares superiores. Foram monitorados nos períodos pré, trans e pós-operatórios, para a pressão arterial e freqüência cardíaca, de modo contínuo, a cada minuto. Os valores dos parâmetros foram obtidos nas fases: 15 minutos antes da anestesia; durante a anestesia tópica; durante a anestesia; por 5 minutos após; durante o preparo cavitário; durante o procedimento restaurador; por 10 minutos após o término. Os pacientes foram divididos em 3 grupos: A (sem pré-medicação); B (precedidos de diazepam - 10 $\mathrm{mg}$ ) e C (precedidos de placebo). Todos receberam anestesia infiltrativa, contendo $1,8 \mathrm{~mL}$ de xilocaina ( $36 \mathrm{mg}$ de lidocaina a $2 \%$ mais $18 \mu \mathrm{g}$ de epinefrina 1:100.000). Não foram encontradas alterações dos parâmetros cardiovasculares durante os procedimentos clínicos. Quando comparados entre si, os grupos apresentaram diferenças estatisticamente significantes na pressão arterial diastólica, durante a anestesia.

\section{REFERENCES}

1. Brand HS, Gortzak RA, Palmer-Buova CC, Abraham RE, Abraham-Inpijn LAL. Cardiovascular and neuroendocrine responses during acute stress induced by different types of dental treatment. Int Dent J 1995;45:45-48.

2. Nakamura Y, Matsumura K, Miura K, Kurokawa H, Abe I, Takata Y. Cardiovascular and sympathetic responses to dental surgery with local anesthesia. Hypertens Res 2001:24:209-214.

3. Silvestre FJ, Verdú MJ, Sanchis JM, Grau D. Effects of vasoconstrictors in dentistry upon systolic and diastolic arterial pressure. Med Oral 2001;6:57-63.

4. Davenport RE, Porcelli RJ, Iacomo VJ, Bonura CF, Mallis GI, Baer PN. Effects of anesthetics containing epinephrine on catecholamine levels during periodontal surgery. J Periodontol 1990;61:553-558.

5. Fernieini EM, Bennett JD, Silverman DG, Halaszynski TM. Hemodynamic assessment of local anesthetic administration by La- ser Doppler flowmetry. Oral Surg Oral Med Oral Path Oral Rad Endod 2001;91:526-530.

6. Miller RA, Siegeman LI. Dental anesthetic management of patient with ventricular arrhythmias. Anesth Prog 1998;45:68-73.

7. Cioffi GA, Terezhalmy GT, Chenow B, Lake RC, Glahn A. The hemodynamic and plasma catecholamine responses to routine restorative dental care. J Am Dent Assoc 1985;111:67-70.

8. Felpel LP. Anxiety drugs and centrally acting muscle relaxants. In: Pharmacology and Therapeutics for Dentistry. Neidle EA, Yagiela JA. eds. $3^{\text {rd }}$ edn. St Louis: Mosby; 1998. p. 168-183.

9. Niwa H, Satoh Y, Matsuara H. Cardiovascular responses to epinephrine-containing local anesthetics for dental use: a comparison of hemodyamic responses to infiltration anesthesia and ergometer-stress testing. Oral Surg Oral Med Oral Pathol Oral Radiol Endod 2000;90:171-181.

10. Paramaesvaran M, Kingon AM. Alterations in blood pressure and pulse rate in exodontia patients. Aust Den J 1994;39:282-286.

11. American Dental Association \& American Heart Association. Management of dental problems in patients with cardiovascular diseases. J Am Dent Assoc 1964;68:33-34.

12. Armonia PL. Efeitos cardiocirculatórios provocados pelo cloridrato de lidocaína $20 \mathrm{mg} / \mathrm{ml}$ associado ao cloridrato de fenilefrina $400 \mu \mathrm{g} / \mathrm{ml}$ (Novocol $100^{\circledR}$ ), em decorrência de sua administração intravascular (Estudo experimental em cães). [Doctoral thesis] São Paulo: Faculdade de Odontologia, Universidade de São Paulo; 1990. 103p.

13. Meechan JG, Parry G, Rattray DT, Thomason JM. Effects of dental local anaesthetics in cardiac transplant recipients. Br Dent J 2002;192:16-13.

14. Faraco, FN. Avaliação das pressões arteriais sistólica, diastólica e média e freqüência cardíaca após a administração endovenosa do cloridrato de lidocaína a $2 \%(20 \mathrm{mg} / \mathrm{ml})$ associado ao cloridrato de noradrenalina $(20 \mu \mathrm{g} / \mathrm{ml})$, em ratos acordados. [Master's thesis] São Paulo: Faculdade de Odontologia, Universidade de São Paulo; 1994. 70p.

15. Rocha RG. Efeitos cardiocirculatórios provocados pelo cloridrato de lidocaína a $2 \%$ associado ao cloridrato de fenilefrina 1:2.500, em cães, decorrentes da administração infiltrativa intra-bucal (Contribuição ao estudo). [Doctoral thesis] São Paulo: Faculdade de Odontologia, Universidade de São Paulo; 1990. 83 p.

16. Knoll-Kohler E, Knoler M, Becker J. Cardiohemodynamic and serum catecholamine response to surgical removal of impacted mandibular third molars under local anesthesia: a randomized double-blind parallel group and crossover study. J Oral Maxillofac Surg 1991;49:957-962.

17. Abraham-Inpijn LAL, Borgmeijer-Hoelen AB, Gortzac RAT. Changes in blood pressure, heart rate and electrocardiogram during dental treatment with use of local anesthesia. J Am Dent Assoc 1988;116:531-536.

18. Campbell R, Langston WG, Ross GA. A comparison of cardiac rate-pressure product and pressure-rate quotient with Holter monitoring in patients with hypertension and cardiovascular disease: a follow-up report. Oral Surg Oral Med Oral Pathol 1997;84:125128.

19. Beck FM, Weaver JM. Blood pressure and heart responses to antecipated high-stress dental treatment. J Dent Res 1981;1:2629. 